\title{
Contribution of Design Indicators in Perception of Social Capital, and Interference of Socio-Demographic Information in the Process
}

\author{
Akbar Rahimi ${ }^{1, *}$, Mahsa Tarashkar ${ }^{2}$ and Banafshe Jahantab ${ }^{2}$ \\ 1 Department of Landscape Architecture, Faculty of Agriculture, University of Tabriz, Tabriz, \\ 29 Bahman Boulevard, Tabriz 5166616471, Iran \\ 2 Faculty of Agriculture, University of Tabriz, Tabriz, 29 Bahman Boulevard, Tabriz 5166616471, Iran; \\ m.tarashkar@tabrizu.ac.ir (M.T.); Banafshejahantab@gmail.com (B.J.) \\ * Correspondence: akbar.rahimi@tabrizu.ac.ir; Tel.: +98-413-339-2043
}

Citation: Rahimi, A.; Tarashkar, M.; Jahantab, B. Contribution of Design Indicators in Perception of Social Capital, and Interference of Socio-Demographic Information in the Process. Sustainability 2021, 13, 3589. https://doi.org/10.3390/ su13073589

Academic Editor: Adela García-Aracil

Received: 19 January 2021

Accepted: 12 February 2021

Published: 24 March 2021

Publisher's Note: MDPI stays neutral with regard to jurisdictional claims in published maps and institutional affiliations.

Copyright: (c) 2021 by the authors. Licensee MDPI, Basel, Switzerland. This article is an open access article distributed under the terms and conditions of the Creative Commons Attribution (CC BY) license (https:/ / creativecommons.org/licenses/by/ $4.0 /)$.

\begin{abstract}
Social capital is the effective contribution of social groups through providing a context for cooperation, sense of identity, and perception of social norms. Urban parks are important components of cities, helps building the social capital within urban societies. This study examines the social capital of important urban parks of Tehran, Iran, using three main criteria: informal social control, social cohesion, and social leverage. A stratified random sample of 330 users were selected and asked to rank the social capital criteria using a questionnaire involving five-point Likert scale questions. The results show mutual relationship between informal social control and social leverage $(r=0.62, \alpha=0.00)$, and also inter-relationship between design indicators and perceived social capital. People from lower age group and higher educational level show highest perception of social capital. Perceptual difference were observed between genders. Women experience higher esthetic perception $(\alpha=0.00)$, security $(\alpha=0.01)$, and accessibility $(\alpha=0.03)$. The study, while proving the relationship between social indicators and design features, and the impact of personal characteristics on the perception of social capital, indicates social inequality in citizens' equal benefit of social capital. Measures must be taken to increase social capital in society and solve the significant lower perceptions of some social capital indicators among specific groups.
\end{abstract}

Keywords: urban parks; cohesion; leverage; informal control

\section{Introduction}

Urban parks are important parts of urban societies, with a tangible role in community development and social cohesion through providing opportunities and places for social interactions [1]. These places are contexts where different age groups, genders, educational levels, and economic statuses participate in individual and collective passive and active activities [2] and build their social capital. Urban parks in developing countries are negatively affected by population growth, and the opportunity to access and benefit from these spaces has been overshadowed by construction, population, and pollution. These challenges are expected to grow in the future; the proportion of the population living in urban areas is expected to increase from $53 \%$ to $70 \%$ by the middle of the 21 st century [3]. In the limited available spaces, the right balance between design and social aspects are necessary to attract visitors and should be considered in any planning and design [4]. Therefore, the possible impact of design elements on the perception of social capital is not far from mind. The concept of social capital depends on the perceptions of public users, and their personalities and preferences, and expert knowledge only appears in providing clues to users (e.g., simple or photo- questionnaire) to evaluate design elements. The goal of this work is to gain an insight into how the social capital is realized in the context of urban parks. In cases such as the present study, where various elements within the park are directly visible to users, a simple questionnaire helps to achieve the goal. 


\subsection{Defining Social Capital}

To evaluate the social capital, there is a need to define and understand the basics of social capital from previous studies. Social aspects built on values and norms constitute the concept of social capital in literature $[5,6]$. Three dimensions of social capital including informal social control, social cohesion, and social leverage have been investigated in the urban parks [7]. Social cohesion indicates the quality of life [8], and involves sense of connectedness [8], sense of trust, belonging to place, and acceptance [9]. Social cohesion can make sense in public places, such as urban parks [10], and is the guarantor of health and well-being of urban dwellers [11]. Informal social control is to keep social order and keep the place safe from criminal and delinquent activities through controlling human behavior [12]. Informal control can reduce health-damaging behaviors within urban parks [13]. Satisfaction and attachment with formal control could increase informal control [14]. Social leverage have been taken to the mean of social inclusion, and is obtained through a suitable platform for active participation [15].

\subsection{Social Capital within the Urban Areas}

The literature contains evidence on how social capital can make sense in the urban places and the city park. Hartig et al. [9] demonstrated that nature can promote social activity and thus tighten social cohesion. In their study nature has been taken to the mean of physical features of environment. Jennings et al. [16] discussed that social interactions in the urban landscapes can catalyze social cohesion. Therefore, social interaction is an important criterion of social cohesion. Peters et al. [17] explored the impact of various factors on social interaction within the urban parks using quantitative and qualitative methods. They proved that physical activities, design features, location of the park, and public perception of spatial configuration of elements can promote social cohesion. They also found differences within different socio-demographic groups towards social cohesion. In addition, it has been proven that participation in park organizations leads to a higher perception of social cohesion in New Orleans stronger [7]. Studies in Chicago found that neighborhood social connections are in close relationship with the amount of urban green spaces $[18,19]$. In addition, a study showed the impact of greenery on social integration [20].

Studies have also examined the impact of design elements, separately and in detail. Perception of social capital is higher in walkable environments, compared to car-dependent places [21,22]. Availability of shaded areas and activities promoting design features might improve social capital through providing activity opportunities [17]. Accessibility and walkability [23-25], and access to public transportation systems [26] have been also identified to be effective in the perception of social cohesion. Several previous studies also found that aesthetic features within the urban parks can promote social cohesion [27-29]. In fact, people hold aesthetics values towards the urban environment, which can impact social and cultural ties. In summary, higher levels of shaded areas, accessibility and walkability, access to public transportation systems, and aesthetic features might increase the social capital among urban park users.

Mazerolle et al. [30] explored the impact of social ties on criminal activities in Australia and showed that informal social control leads to lower criminal activities within urban environment. Moreover, a study proved that higher perception of informal social control among young adults serves to reduce problematic behaviors in urban societies [31]. Therefore, social control serves to reduce criminal activities. Mehta and Mahato [15] found that urban parks to promote social leverage should include informal and informal seating and informal open areas for group activities such as picnics and should address the different needs of socio-demographic groups. Carr [32] also showed that informal social control becomes highly dominant when people have social leverage and are informed about formal social control. 


\subsection{Personal Characteristics and Perception}

The impact of socio-demographic characteristics on the perception of social capital has been proven in the literature. Pabayo et al. [33] explored the impact of socio-demographic information on social capital perception in Boston, MA, USA. The obtained data included self-reported personal information. They illustrated that perceived social cohesion significantly depends on age, income, and the place of birth. In their study oldest adults and people with the best economic situation had the highest social cohesion. Silver and Miller [14] proved the impact of personal characteristics such as age on the perception of informal social control. Mowen and Rung [7] analyzed the difference in perception of informal social control, social leverage, and social control within socio-demographic groups. They found that participants' characteristics such as their gender, visit duration, age, and cultural factors significantly affect their perceived social capital. Nguyen [34] found that with an increase in age civic and political participation goes up, which indicates a positive relationship between age and social capital. Miller [35] investigated the impact of education on social capital and showed that education and learning experience can severely impact social capital. Some other studies showed that perception of landscape features is influenced by personal characteristics such as educational level [36], social and economic status [37], age and gender [38-43]. Further, studies found the impact of personal characteristics on perception of design and aesthetic features. Studies demonstrated that women's age, income, and education affect their perceptual preferences for landscape elements [44], and spatial configuration [45].

The perceptions of different socio-demographic groups across these studies show that perception pattern is culture and place specific. But in general, it can be expressed that perception is affected by personal characteristics. Therefore, the perception of social capital significantly differs among persons, cultures, and societies. So, it is worth studying social capital within specific urban parks of Tehran, where such studies have not been pursued with the utmost seriousness. In addition, the relationship between social capital and personal characteristics has not been previously explored. Therefore, the current study aims exploring the nature of social capital and integrating social capital with design criteria and also demographic characteristics of users in the urban parks.

The following hypotheses have been assigned to the study:

- There is interrelationship between social capital indicators.

- Design features are involved in the perception of social capital.

- Social characteristics impact the perception of social capital and design.

In addition to proving the study hypotheses, this study leads to bringing attention to specific demographic features of studies urban parks. New aspects of differences between genders, age groups and educational levels are also addressed in detail.

\section{Materials and Methods}

\subsection{Study Area}

The experiment was carried out in three urban parks located in the 6th Urban District of Tehran. The city is located at northern part of Iran and has been the capital of the country since ancient times. It is the most populated (8.694 million, according to the 2016 census) and largest city of the county. Tehran has been a destination for immigrants from all over Iran since the 20th century. The 6th District of Tehran is a cultural hub, with several libraries, bookstores, theaters and the University of Tehran. The study participants were selected from important parks of the region such as Laleh Park, Shafaq Park, and Saei Park. Laleh Park was designed by famous French designer "Zhufeh", and constructed by Tehran municipality in 1966. Saei Park was built in 1950 as an urban forest by the efforts of Karim Saei, a professor at the University of Tehran, and has been used as Saei Public Park since 1962. Shafaq Park was built according to a plan inspired by French parks. Uneven paths in combination with stairs constitute the main features of this park (Figure 1). 

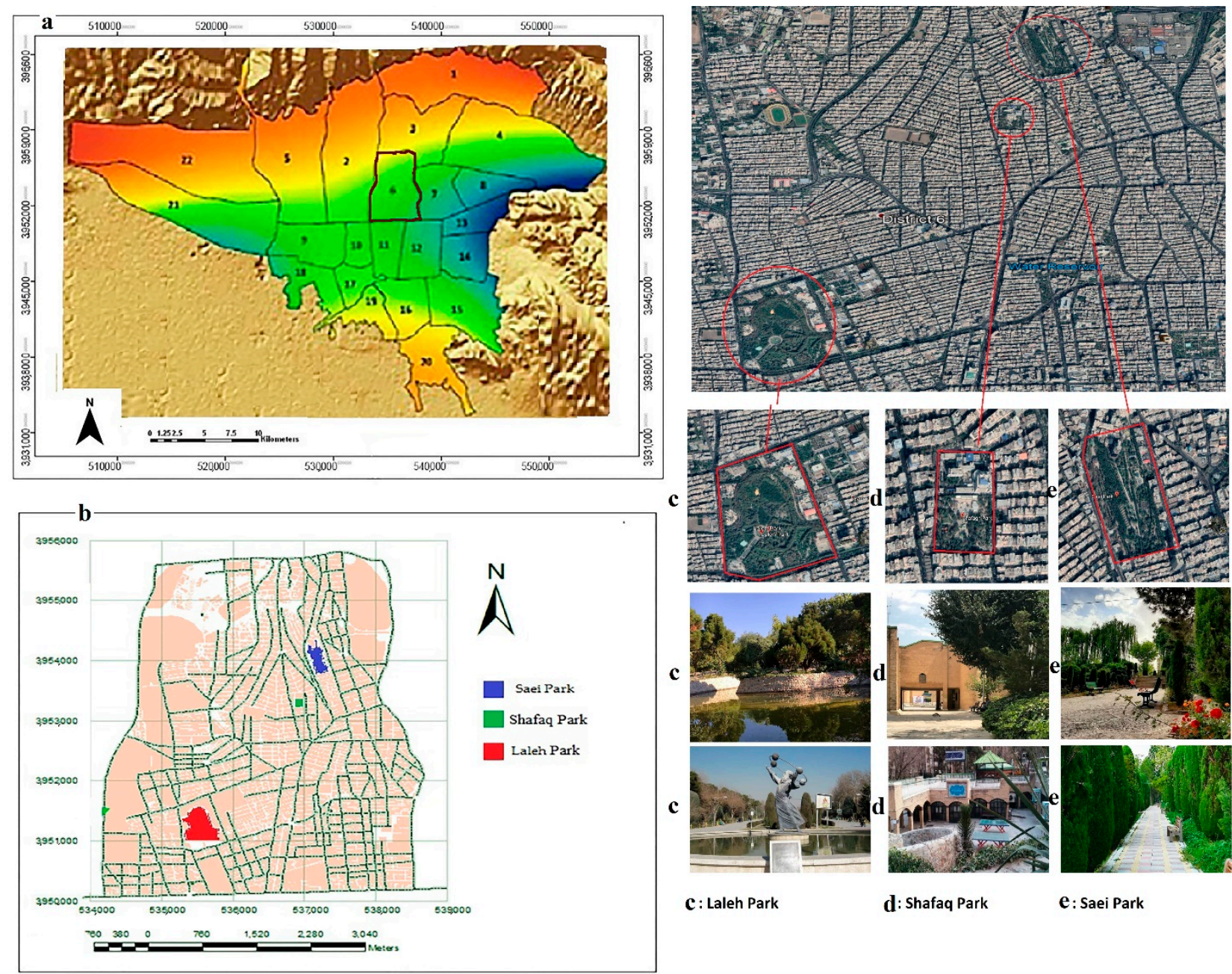

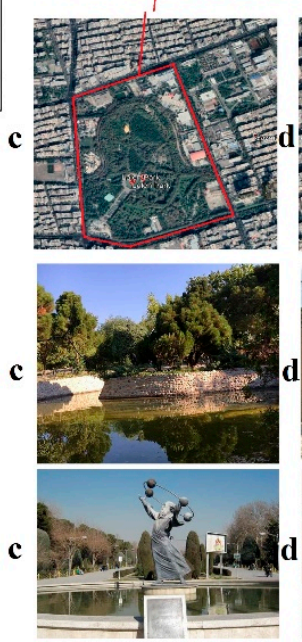

c: Laleh Park

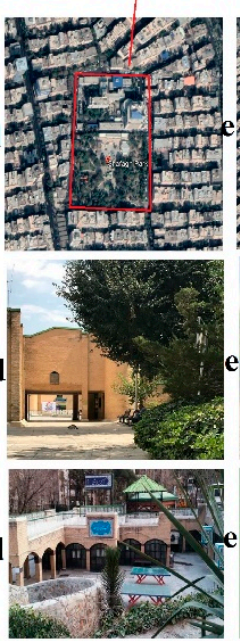

d: Shafaq Park

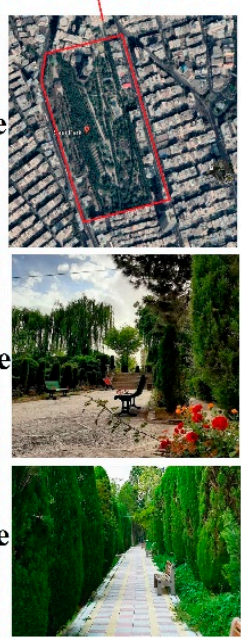

e: Saei Park

Figure 1. Tehran and urban zones (a), and the urban parks within the 6th urban zone (b), Saei Park (c), Shafaq Park (d), and Laleh Park (e).

\subsection{Study Procedure}

To design the study, a group of twenty landscape, social science, and urban planning experts were invited to a meeting at the University of Tabriz Faculty of Agriculture. After a detailed discussion on the subject and objectives of the study, questions were designed to evaluate social capital. Questions of perceived informal social control were those assessing the feeling of being in control in terms of misbehaviors and conflicts with others. In addition, the sense that addicts are not allowed enter the park. Social leverage assessed active participation in park maintenance, planning, and design, and also a sense of responsibility to work as a volunteer guard or gardener. Social cohesion assessed social interactions and the desire to do collective activities, sense of belonging, and a sense of acceptance. Security questions were those investigating the suitable position and form of various types of plants in various parts of the parks including picnic areas, and also position of live (hedges) and non-live barriers, and straight or curved planted paths to allow opportunities for supervision on criminal acts and misbehavior, and inducing safety. Questions of aesthetic perception explore perceptual preferences for various types of plants around fountains, and within picnic areas, and along the paths. Accessibility was explored through questions investigating access to private or public transportation systems, and also potential barriers to access such as traffic and disability.

The reliability was checked out using a pilot study, and Cronbach's alpha coefficients were controlled to be above 0.7 . The target study population for questionnaire survey were 
users of Laleh Park, Saei Park, and Shafaq Park. The sample size was determined using the Mitra and Lankford formula. The standard deviation was assumed to be equal to 2.75 with the sampling size amounting to 330 persons. Assuming that urban parks of a specific urban zone may provide homogeneous data, a stratified random sample of visitors within three urban parks of the 6 th zone were selected. This assumption has been checked out using statistical analysis. Thus, 110 questionnaires were distributed every day in each of the parks, during the summer of 2018 at $10 \mathrm{am}$ to $2 \mathrm{pm}$ and $4 \mathrm{pm}$ to $8 \mathrm{pm}$ [44]. After completing the questions on socio-demographic information, participants were asked to answer five-point Likert scale questions about social capital and design features.

\subsection{Statistical Analysis}

The data obtained from questionnaire survey were analyzed using SPSS Statistics 25 (It was acquired by IBM, International Business Machines Corporation, in 2009. Current versions have the brand name: IBM SPSS Statistics). Frequency analysis was used to identify the socio-demographic characteristics of the participants. Descriptive statistics were used to describe the basic features of the data and mean values and standard deviation were calculated. The reliability of the questionnaires for the studied criteria were checked out using reliability analysis and Cronbach's alpha. The relationship between social capital criteria and also their relation with design indicators were examined using B- variate correlation analysis. The difference in perception of genders were determined using $t$-tests. Moreover, different perceptions between age groups, educational levels, and frequent or occasional users were calculated using one-way ANOVA.

\section{Results}

Demographic attributes of the respondents are shown in Table 1. Since questionnaires were randomly distributed, it can be concluded that most of the users are women $(n=194$, $58.8 \%)$. A majority of them visit the parks once a week $(n=103,31.2 \%)$. The $26-35$ age group constitutes the majority of park users $(n=110,31.3 \%)$, and most of the users have a Bachelor of Education degree $(n=135,40.9 \%)$. According to the report of the Statistical Organization of Iran, student dormitories in the 6th District of Tehran have completely affected the demographic and social context. Therefore, the random distribution of the questionnaire was successful, and the results of this research are applicable to the 6th District of Tehran.

Table 1. Demographic attributes of respondents.

\begin{tabular}{cccc}
\hline Independent Variable & Category & Frequency Distribution & Percentage \\
\hline \multirow{2}{*}{ Gender } & Man & 136 & 41.2 \\
& Woman & 194 & 58.8 \\
\hline \multirow{3}{*}{ Age } & Under 25 & 30 & 9.1 \\
& $26-35$ & 110 & 31.3 \\
& $36-45$ & 108 & 32.7 \\
& $46-55$ & 56 & 17 \\
& Above 56 & 26 & 7.9 \\
\hline \multirow{3}{*}{ Level of education } & Under diploma & 21 & 6.4 \\
& Diploma & 40 & 18.5 \\
& College & 18 & 5.5 \\
& Bachelor & 135 & 40.9 \\
& Master & 85 & 25.8 \\
& Above master & 31 & 9.4 \\
\hline \multirow{3}{*}{ Amount of park visits } & Every day & 43 & 13 \\
& Once a week & 103 & 31.2 \\
& Once a month & 101 & 30.6 \\
& Seldom & 83 & 25.2 \\
\hline Total of each variable & & 330 & 100 \\
\hline
\end{tabular}


The questions were designed by a group of experts. The reliability analysis was performed to ensure the ability of questions to explore the public perceptual preference for a considered indicator. The Cronbach's alpha coefficients higher than 0.7 were achieved for all variables (Table 2). Descriptive analysis was done to obtain an overview of the variables (Table 2). Skewness values are between -1 and 1 , and Kurtosis values were between -3 and 3 , and thus in an acceptable range [46]. In terms of design factors, people are more satisfied with the aesthetic features of the parks $(\mathrm{M}=3.94, \mathrm{SD}=0.72)$, followed by accessibility $(\mathrm{M}=3.66, \mathrm{SD}=0.80)$ and security $(\mathrm{M}=03.28, \mathrm{SD}=0.95)$. Social leverage $(\mathrm{M}=2.78, \mathrm{SD}=1.02)$ is the most perceived social capital among visitors, followed by informal social control $(\mathrm{M}=2.73, \mathrm{SD}=1.12)$, and social cohesion $(\mathrm{M}=2.65, \mathrm{SD}=0.96)$. Therefore, perceptual preferences were moderate for both design and social capital indicators. This method has been used to describe the state of perceptual preferences in a previous study [2].

Table 2. Descriptive and reliability analysis for design indicators and social capital criteria.

\begin{tabular}{cccccccc}
\hline \multicolumn{7}{c}{ Descriptive Analysis } \\
\hline Variable & Mean Values & SD & $\begin{array}{c}\text { Cronbach's } \\
\text { Alpha }\end{array}$ & Variable & Mean Value & $\begin{array}{c}\text { SD } \\
\text { Cronbach's } \\
\text { Alpha }\end{array}$ \\
\hline Aesthetics & 3.94 & 0.72 & 0.80 & Social leverage & 2.78 & 1.02 & 0.81 \\
Accessibility & 3.66 & 0.80 & 0.80 & Informal social control & 2.73 & 1.12 & 0.81 \\
Security & 3.28 & 0.95 & 0.71 & Social cohesion & 2.65 & 0.96 & 0.80 \\
\hline
\end{tabular}

Following to the similar studies in the field [44], B-variate correlation was first performed to determine the relationship between social capital indicators. The results manifested the relationship between social capital indicators. Moderately strong correlation was detected between social leverage and informal social control $(\mathrm{r}=0.62, \alpha=0.00)$. Therefore, any practical action to increase informal social control leads to increases in social leverage, and vice versa. The relationship between informal social control and social cohesion was statistically insignificant (Table 3). This result is supported by findings of Carpiano [47], who found significant correlation between these two criteria in Los Angeles (CA, USA). Thus, it can be concluded that the relationship between informal social cohesion and social leverage depends on their inherent nature.

Table 3. B-variate correlation between social leverage and informal social control.

\begin{tabular}{ccc}
\hline & & Social Leverage \\
\hline \multirow{2}{*}{ Informal social control } & Correlation Coefficient & $0.62 * *$ \\
& Sig. (2-tailed) & 0.00 \\
\hline
\end{tabular}

Pearson correlation coefficient: $<0.3$ negligible correlation, $0.3-0.5$ weak, correlation, $0.5-0.7$ moderately strong correlation, $0.7-0.9$ strong correlation, $>0.9$ very strong correlation (Hinkle et al., [48]). ${ }^{* *} p<0.01$.

The B-variate correlation was also performed to determine the relationship between social capital and design indicators. As seen in Table 4, social leverage is in significant relation with accessibility $(r=0.6, \alpha=0.00)$, and perceived security $(r=0.4, \alpha=0.00)$. Informal social control is correlated with security $(r=0.6, \alpha=0.00)$, and accessibility $(\mathrm{r}=0.4, \alpha=0.00)$. In addition, social cohesion is associated with accessibility $(\mathrm{r}=0.52$, $\alpha=0.00)$, and also aesthetic aspects $(r=0.5, \alpha=0.00)$. According to the findings (Table 2), perceptual preferences are moderate for all three variables of access security and aesthetics. The same as other studies [21-29], perception of social capital in the 6th district of Tehran is in close relationship with design features. These comprehensive study makes it possible to determine if a specific design feature impacts several social capital dimensions. For instance, the results in Table 4 prove that accessibility impacts all dimensions of social capital. In previous studies, accessibility has often been considered in relation to social cohesion [23-25]. Given the significant correlation, improving each design indicator increases social capital. The most influential factor is accessibility, followed by security and aesthetic. 
Table 4. B-variate correlation between social capital and design.

\begin{tabular}{|c|c|c|c|c|}
\hline Indicator & & Security & Accessibility & Aesthetic \\
\hline \multirow[t]{2}{*}{ Social leverage } & $\begin{array}{c}\text { Correlation } \\
\text { coefficient }\end{array}$ & $0.4^{* *}$ & $0.6^{* *}$ & - \\
\hline & Significance & 0.00 & 0.00 & - \\
\hline \multirow[t]{2}{*}{$\begin{array}{l}\text { Informal social } \\
\text { control }\end{array}$} & $\begin{array}{c}\text { Correlation } \\
\text { coefficient }\end{array}$ & $0.65^{* *}$ & $0.4^{* *}$ & - \\
\hline & Significance & 0.00 & 0.00 & - \\
\hline \multirow[t]{2}{*}{ Social cohesion } & $\begin{array}{c}\text { Correlation } \\
\text { coefficient }\end{array}$ & - & $0.52^{* *}$ & $0.5^{* *}$ \\
\hline & Significance & - & 0.00 & 0.00 \\
\hline
\end{tabular}

The study primarily sought to examine the effect of gender on perception. The results of independent sample $t$-test was used to prove interferes of gender differences in perception of those of design indicators related to social capital perception (Table 5, Figure 2). So, perception of design indicators significantly differs between genders, and women have highest perception of security $(\mathrm{T}=-2.49, \alpha=0.01)$, attractiveness $(\mathrm{T}=-3.70$, $\alpha=0.00)$, and accessibility ( $\mathrm{T}=-2.20, \alpha=0.03)$. It is believed that access to public amenities is lower for women living in Iran, compared to more liberated societies [49]. However, the results of the current study were contrary to those of previous research. These results can be related to the demographic context of the region. Today, most of the university students in Iran are women. Such a socio-demographic context has dominated the use and preferences of women. The most significated difference was manifested in terms of aesthetic aspects. Therefore, the aesthetic features of the studied urban parks are more successful to attract the attention and interest of women than men. In general, the park is more successful in satisfying women's perceptual preferences. Another study in the UK showed that women experience higher social capital [7]. The psychological and mental characteristics of women may be responsible for higher perceptions, but further research is needed to prove the claim.

Table 5. Independent sample $t$-test between design indicators and genders.

\begin{tabular}{ccccccc}
\hline & \multicolumn{2}{c}{ Men } & & & Df & Sig. (2-Tailed) \\
\cline { 2 - 3 } & Women & Men & & & D & \\
\hline Security & 3.18 & 3.41 & & -2.49 & 328 & 0.01 \\
Accessibility & 3.58 & 3.77 & & -2.20 & 328 & 0.03 \\
Aesthetics & 3.82 & 4.11 & -3.70 & 328 & 0 \\
\hline
\end{tabular}

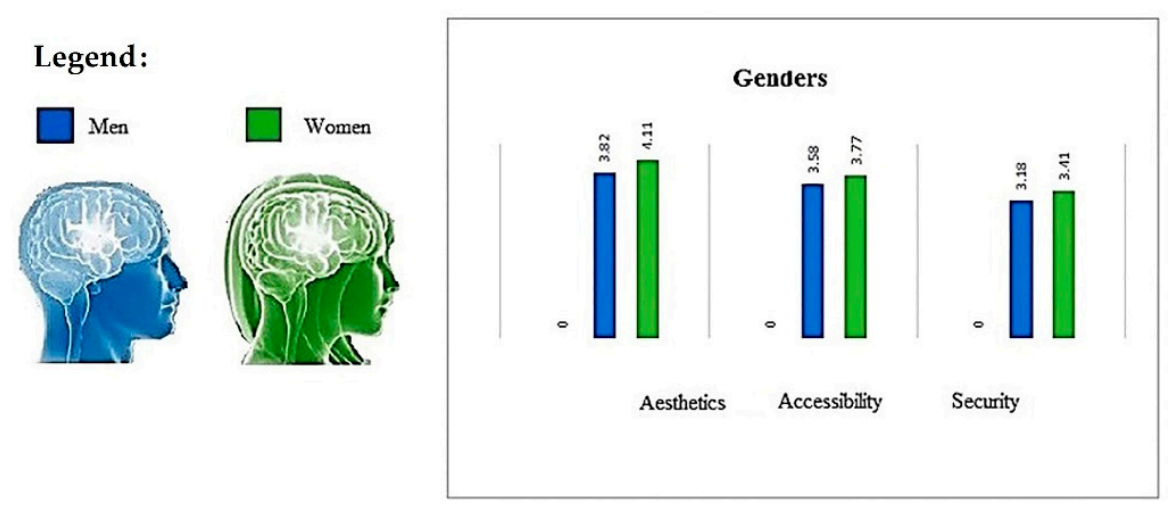

Figure 2. Graphic illustration of differences between genders. 
The study also sought to examine the effect of formal education on perception. As seen in Table 6 and Figure 3, security perception varies between people having different educational status " $\mathrm{F}(324,5)=3.10, \alpha=0.009$ ". With increases in education, security perception goes up. Under diploma $(\mathrm{M}=3.00)$, diploma $(\mathrm{M}=3.05)$, and college $(\mathrm{M}=3.20)$ educational groups show significant differences with the PhD group $(M=3.77)$. The Bachelors and Masters degree educational groups do not show significant differences with other groups, but an increasing trend is always observed with education. Similar to security, social cohesion increases with education. But the only significant difference is observed between under diploma $(\mathrm{M}=3.00)$ and $\mathrm{PhD}$ educational levels $(\mathrm{M}=3.77)$. In another study in Tabriz, Iran, perceptual preferences for plants (trees, shrubs, and flowers) showed growing trend with increases in education [44]. This increasing pattern was also detected for perceptual preferences for planting designs [45]. Formal education leads to an increase in self-confidence and awareness, and thus higher perception of social cohesion and security.

Table 6. One-way ANOVA results for security/social cohesion and education.

\begin{tabular}{|c|c|c|c|c|c|c|c|c|c|}
\hline & \multicolumn{6}{|c|}{ Education } & \multirow{2}{*}{ Df } & \multirow{2}{*}{$\mathbf{F}$} & \multirow{2}{*}{ Sig. } \\
\hline & Under Diploma & Diploma & College & Bachelor & Master & PhD & & & \\
\hline Security & $3.00^{\mathrm{a}}$ & $3.05^{\mathrm{a}}$ & $3.20^{a}$ & $3.22^{a b}$ & $3.41^{\mathrm{ab}}$ & $3.77^{b}$ & 5 & 3.1 & 0.009 \\
\hline Cohesion & $2.10^{\mathrm{a}}$ & $2.55^{\mathrm{ab}}$ & $2.7^{a b}$ & $2.75^{a b}$ & $2.78^{a b}$ & $3.05^{b}$ & 5 & 3.42 & 0.005 \\
\hline
\end{tabular}

Note: Cell entries are mean values based on 5 -point Likert scale ( $1=$ very low, $2=$ low, $3=$ moderate preferred, $4=$ high, $5=$ so high). The raw mean with different superscript differ significantly at $p<0.05$. The Tukey method was used for the post-hoc test.

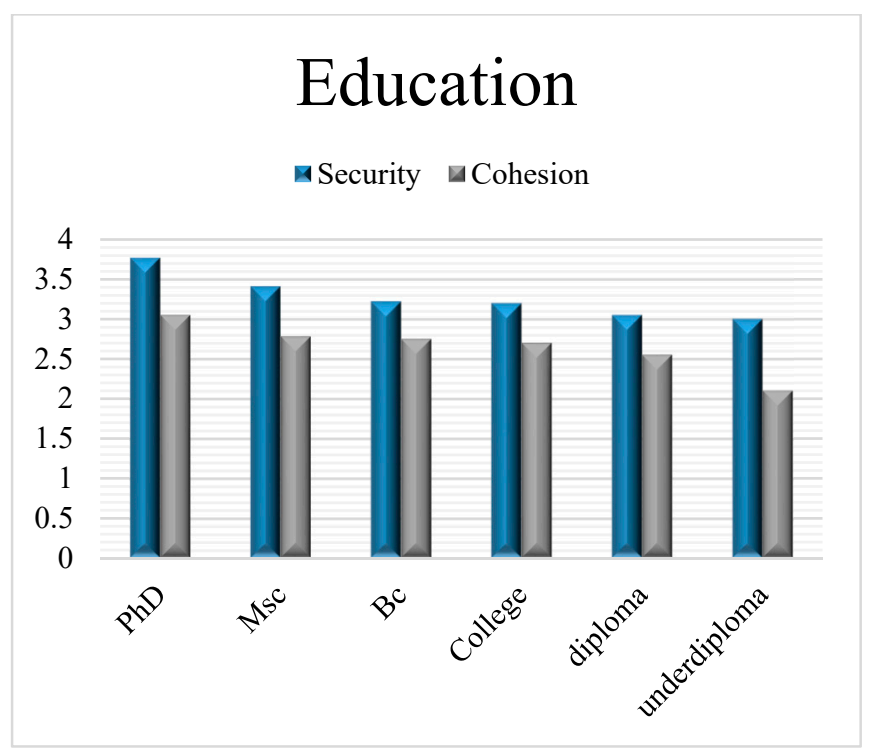

Figure 3. Graphic illustration of changes in safety perception and cohesion by education.

Age is also an influential factor in the perception process. Informal social control significantly varies within age groups " $\mathrm{F}(325,4)=2.83, \alpha=0.02$ ", and shows a decreasing trend. In the study of Hami and Tarashkar [44], the perceptual preferences for plants increased with age, but the pattern of changes in their study was quite different. Therefore, social, cultural, and environmental features are determining factors, but the constant principle is the variability of perception with age. The difference between 15-25 and over 55 groups is statistically significant. According to the descriptive mean values (Table 2), social cohesion (Mean $=2.65$ ) is not in suitable conditions. Still, the results of one-way ANOVA using the Tukey HSD shows significant differences among age groups " $F(325,4)$ $=3.37, \alpha=0.01$ " towards social cohesion. While above 55 years old people have the lowest 
sense of social cohesion (Mean $=2.11), 15$ to $25($ Mean $=2.83)$ and 26 to $35($ Mean $=2.69)$ year-old people have the highest perception of social cohesion (Table 7 and Figure 4). Due to the demographic context and housing of young people in this urban zone, higher social capital is perceived by this group.

Table 7. One-way ANOVA results for informal social control/ social cohesion and age groups.

\begin{tabular}{|c|c|c|c|c|c|c|c|c|}
\hline & \multicolumn{5}{|c|}{ Age } & \multirow{2}{*}{ Df } & \multirow{2}{*}{$\mathbf{F}$} & \multirow{2}{*}{ Sig. } \\
\hline & Under 25 & $26-35$ & $36-45$ & $46-55$ & $>55$ & & & \\
\hline Informal social control & $3.2^{\mathrm{a}}$ & $2.81^{\mathrm{ab}}$ & $2.68^{a b}$ & $2.65^{a b}$ & $2.27^{b}$ & 4325 & 2.83 & 0.02 \\
\hline Social cohesion & $2.83^{\mathrm{a}}$ & $2.69^{a}$ & $2.53^{\mathrm{ab}}$ & $2.5^{\mathrm{ab}}$ & $2.11^{\mathrm{b}}$ & 4325 & 3.37 & 0.01 \\
\hline
\end{tabular}

Note: Cell entries are mean values based on 5 -point Likert scale ( 1 = very low, $2=$ low, $3=$ moderate preferred, $4=$ high, $5=$ so high). The raw mean with different superscript differ significantly at $p<0.05$. The Tukey method was used for the post-hoc test.

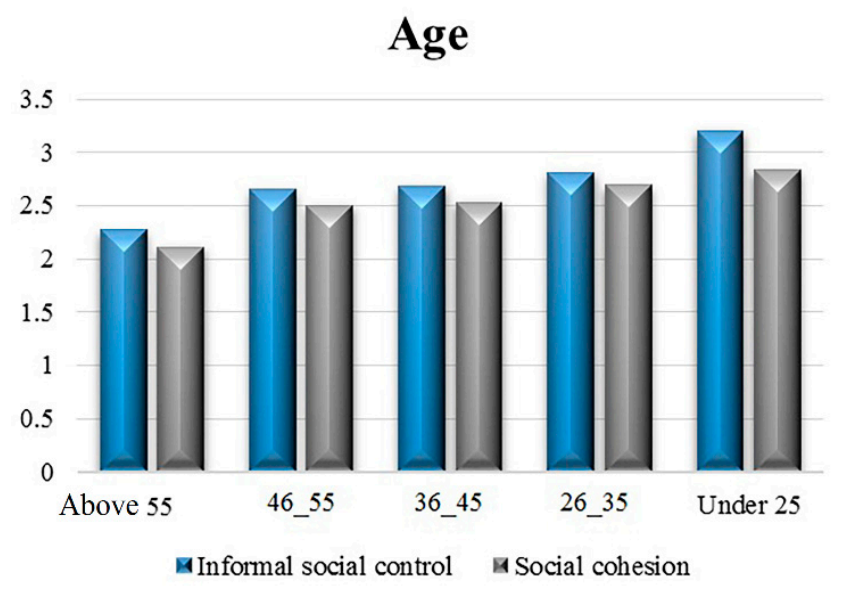

Figure 4. Graphic illustration of changes in informal control and cohesion by age.

Park visit frequency can also influence the social capital. The post-hoc comparisons using the Tukey HSD showed that informal social control " $\mathrm{F}(3,326)=8.11, \alpha=0.00$ )" and social leverage " $\mathrm{F}(3,326)=7.49, \alpha=0.00)$ " could be different according to visit frequency. People who visit the park once a year have lowest social leverage and informal control, showing significant differences with people who visit the park every day and every week. People who visit the parks once a month have significantly lower informal social control $(\mathrm{M}=2.60)$ and social leverage $(\mathrm{M}=2.71)$, compared to the people who visit the parks every day. As is clear in the Table 8 and Figure 5, with increases in visit frequency, perception of social capital goes up. Therefore, encouraging people to visit the parks might increase social leverage and informal social control. This result can be related to familiarity. A previous study [44] proved that familiarity leads to significant increases in perceptual preferences. More visits lead to higher familiarity, and thus higher perceptual preferences.

Table 8. One-way ANOVA results for informal social control/ social leverage and park visits.

\begin{tabular}{ccccccccc}
\hline & \multicolumn{3}{c}{ Visit } & \multirow{2}{*}{ Df } & F & Sig. \\
\cline { 2 - 6 } & Every Day & Every Week & Once a Month & Once a Year & & \\
\hline Informal social control & $3.18^{\mathrm{a}}$ & $2.97^{\mathrm{ab}}$ & $2.60^{\mathrm{bc}}$ & $2.35^{\mathrm{c}}$ & 3326 & 8.11 & 0.00 \\
\hline Social leverage & $3.19^{\mathrm{a}}$ & $2.97^{\mathrm{ab}}$ & $2.71^{\mathrm{bc}}$ & $2.42^{\mathrm{c}}$ & 3326 & 7.49 & 0.00 \\
\hline
\end{tabular}

Note: Cell entries are mean values based on 5 point Likert scale $(1=$ very low, $2=$ low, $3=$ moderate preferred, $4=$ high, $5=$ so high). The raw mean with different superscript differ significantly at $p<0.05$. The Tukey method was used for the post-hoc test. 


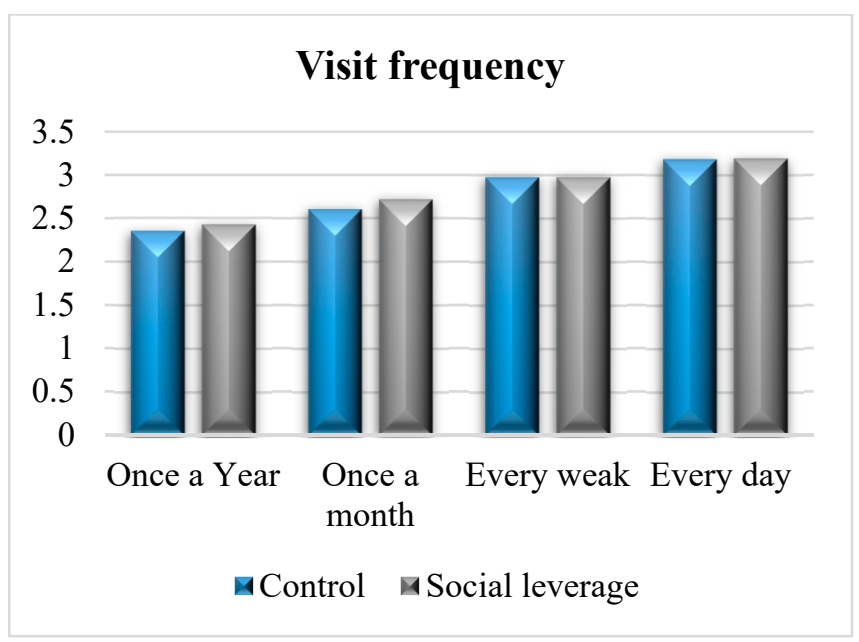

Figure 5. Graphic illustration of changes in informal control and leverage by visit frequency.

\section{Discussion}

The study primarily sought to prove the relationship between different social capital indicators. The results show a significant relationship between social leverage and informal social control. Carr [32] showed that informal social control becomes highly dominant when people have social leverage and get information from formal institutions. In addition, previous studies show that informal social control and social leverage have features in common; both informal social control [14] and social leverage [15] increase via cooperation with organizations responsible for formal control, including the police. The results indicate that informal social control is not significantly correlated with social cohesion. Prior studies have also proven than social cohesion is not always highly correlated with informal social control [50]. In addition, social cohesion and informal social control have been shown to have differential impacts and outcomes [51,52].

In an attempt to prove the relationship between landscape features and social capital indicators, we found a significant relationship between security and informal social control. In line with our findings, Carpiano [47] found that informal social control provides health benefits through increasing security perception. This research found that social cohesion depends on aesthetic features of the urban parks. It has been proven that social cohesion is high in landscapes with higher aesthetic features [27-29]. Similar to our findings, studies have found that accessibility leads to higher social cohesion [23-25]. Social cohesion has always been in a close relation with the aspects of built environment [23]. In addition, a previous study showed that various park characteristics such as special attractions (e.g., trees, shrubs, and flowers) can improve social lives and well-being [2,53]. This study makes it clear that sometimes design elements can impact several dimensions of social capital, which is the distinguishing feature of this study. Accessibility impacts all dimensions of the social capital, while security increases the social leverage and informal control, and aesthetic features can only increase the social cohesion.

According to the findings of the current study, women have the highest perception of design indicators. Mowen and Rung [7] have found women's higher perception of social capital criteria within urban parks. Here, the results prove the interdependence between design elements and social capital. Perceptions of security and social cohesion were different between users having different education levels. People with the highest educational level showed the highest sense of safety and cohesion. Perception within urban parks has been proven to be affected by education [44]. Given that this trend is almost always increasing, it is concluded that increases in education might lead to higher self-confidence and awareness. The perception of informal social control was significantly high in people under 25 years old. The primary importance of informal social control is to prevent problematic activities in young people [31]. Therefore, the higher perception of control among youth works to reduce social problems. Previous studies have 
proven the people have willing to control youth behavior and intervene when observing misbehavior [54]. The age group over 55 years have shown lowest social cohesion. Since social capital is illustrative of life satisfaction [5,55], it can be interpreted that people over 55 are the least satisfied with their lives. Since the current study shows a significant strong relationship between social cohesion and aesthetic features, low social cohesion partially originates from dissatisfaction with the aesthetic features of the parks. It has been proven that social capital protects public mental health and well-being [56,57]. Salvatore and Grundy [58] showed that deprivation can decrease public mental health and perceived social cohesion. They also proved the mutual relation between neighbourhood social cohesion and mental health. Lee et al. [59] have also shown a close relationship between social capital and depression. Lower levels of social capital among older adults in Italy affects the quality of life through reducing mental health and resilience to life problems [60], yet, identifying the exact reason is a topic for future studies.

The young age group has significant higher social cohesion, compared with the highest age group. Social connection is important for elderly users [61]. Social involvement is shown to be affected by individuals' access to information [62]. This study similarly shows that the social involvement (informal control and leverage) varies between people depending on their visit frequency; people who visit the parks every day have higher social leverage and higher informal control. Therefore, people should be encouraged to visit the parks more. A previous study proved the direct relationship between familiarity and perceptual preferences [44]. The relationship between visit frequency and social capital can be related to perceived familiarity, so that a higher visit frequency impacts perceptual preferences through increasing familiarity.

\section{Conclusions}

The study investigated the interference of flowers, shrubs, trees (size, shape, color, and variety) with the aesthetic and security perception of public users. Although there are technical differences in the way the three parks are planted, there was no statistically significant difference in public perception. Landscape is a concept including the perception and experience and given the impact of culture and context on the perceptual preferences, planning in each country, city, and region should be done exclusively, and generalization from other places will not be helpful. In summary, studies should be site-specific. This study was carried out in one of the most prosperous regions of the country and the presence of student dormitories have completely affected the socio-demographic context of the district. The special demographic context of this region has provided better conditions for the social life of young people, including their higher sense of social cohesion. Higher education leads to higher cohesion and security perception. In addition, people having higher park visit frequency experience higher informal social control and social leverage. It is possible to increase social capital through facilitating accessibility to the parks and providing facilities for people with disabilities. Encouraging individuals to visit the parks more through natural attractions and inducing a sense of security can also be effective.

In the urban parks of the 6th District of Tehran, older and less educated people face the problem of low perceived social capital. Therefore, measures must be taken to deal with the problem. In addition, efforts should be made to establish gender justice and also to eliminate significant differences in the perceptions of men and women. Sense of safety can be equalized through inducing perception of informal social control in both genders. Equal satisfaction with aesthetic features could be achieved by balancing the desired design elements of men and women. Higher accessibility may be due to higher unemployment levels of women compared to men. Assessing the exact cause of women's higher accessibility is a task for future studies. In addition, subsequent studies in other zones of Tehran will provide valuable comparisons.

Author Contributions: Writing—original draft, A.R., M.T. and B.J. All authors have read and agreed to the published version of the manuscript. 
Funding: This research was funded by University of Tabriz, Iran.

Institutional Review Board Statement: Not applicable.

Informed Consent Statement: Informed consent was obtained from all individual participants included in the study.

Data Availability Statement: The data that support the findings of this study are available on request from the corresponding author.

Acknowledgments: The authors acknowledge the supports provided by department of landscape architecture.

Conflicts of Interest: The authors declare no conflict of interest.

\section{References}

1. Xu, Y.; Matarrita-Cascante, D.; Lee, J.H.; Luloff, A.E. Incorporating Physical Environment-Related Factors in an Assessment of Community Attachment: Understanding Urban Park Contributions. Sustainability 2019, 11, 5603. [CrossRef]

2. Tarashkar, M.; Hami, A.; Namin, F.E. The Effects of Parks' Landscape Characteristics on Women's Perceptual Preferences in Semi-arid environments. J. Arid Environ. 2020, 174, 104080. [CrossRef]

3. UNISDR. Progress and Challenges in Disaster Risk Reduction: A Contribution towards the Development of Policy Indicators for the Post-2015 Framework on Disaster Risk Reduction; The United Nations Office for Disaster Risk Reduction: Geneva, Switzerland, 2014.

4. Vierikko, K.; Goncalves, P.; Haase, D.; Elands, B.; Iojă, I.C.; Jaatsi, M.; Pieniniemi, M.; Lindgren, J.; Grilo, F.; Santos-Reis, M.; et al. Biocultural diversity (BCD) in European cities-Interactions between motivations, experiences and environment in public parks. Urban For. Urban Green. 2019, 20, 126501. [CrossRef]

5. Hassanzadeh, J.; Asadi-lari, M.; Baghbanian, A.; Ghaem, H. Association between social capital, health-related quality of life, and mental health: A structural-equation modeling approach. Croat. Med. J. 2016, 57, 58-65. [CrossRef]

6. Yoo, C.; Lee, S. Neighborhood Built Environments A_ecting Social Capital and Social Sustainability in Seoul, Korea. Sustainability 2016, 8, 1346. [CrossRef]

7. Mowen, A.J.; Rung, A.L. Park-based social capital: Are there variations across visitors with different socio-demographic characteristics and behaviours? Leisure/Loisir 2016, 40, 297-324. [CrossRef]

8. Schiefer, D.; van der Noll, J. The Essentials of Social Cohesion: A Literature Review. Soc. Indic. Res. 2017, 132, 579-603. [CrossRef]

9. Hartig, T.; Mitchell, R.; de Vries, S.; Frumkin, H. Nature and Health. Annu. Rev. Public Health 2014, 35. [CrossRef]

10. Kabisch, N.; Qureshi, S.; Haase, D. Human-environment interactions in urban green spaces A systematic review of contemporary issues and prospects for future research. Environ. Impact Assess. Rev. 2015, 50, 25-34. [CrossRef]

11. Poortinga, W. Social relations or social capital? Individual and community health effects of bonding social capital. Soc. Sci. Med. 2006, 63, 255-270. [CrossRef]

12. Groff, E.R. Informal Social Control and Community Crime Prevention. J. Contemp. Crim. Justice 2015, 31, 90-106. [CrossRef]

13. Lewis, M.A.; Rook, K.S. Social control in personal relationships: Impact on health behaviors and psychological distress. Health Psychol. 1999, 18, 63-71. [CrossRef]

14. Silver, E.; Miller, L.L. Sources of informal social control in Chicago neighborhoods. Criminology 2004, 42, 551-584. [CrossRef]

15. Mehta, V.; Mohato, B. Designing urban parks for inclusion, equity, and diversity. J. Urban. 2020, 1-33. Available online: https:/ / www.tandfonline.com/doi/abs/10.1080/17549175.2020.1816563?journalCode=rjou20 (accessed on 14 January 2021).

16. Jennings, V.; Bamkole, O. The Relationship between Social Cohesion and Urban Green Space: An Avenue for Health Promotion. Int. J. Environ. Res. Public Health 2019, 16, 452. [CrossRef] [PubMed]

17. Peters, K.; Elands, B.; Buijs, A. Social interactions in urban parks: Stimulating social cohesion? Urban For. Urban Green. 2010, 9, 93-100. [CrossRef]

18. Kuo, F.E.; Sullivan, W.C.; Coley, R.L.; Brunson, L. Fertile ground for community: Inner-city neighborhood common spaces. J. Community Psychol. 1998, 26, 823-851. [CrossRef]

19. Sullivan, W.C.; Kuo, F.E.; Depooter, S.F. The fruit of urban nature: Vital neighborhood spaces. Environ. Behav. 2004, 36, 678-700. [CrossRef]

20. Kweon, B.S.; Sullivan, W.C.; Wiley, A.W. Green common spaces and the social integration of inner-city older adults. Environ. Behav. 1998, 30, 832-858. [CrossRef]

21. Rogers, S.H.; Halstead, J.M.; Gardner, K.H.; Carlson, C.H. Examining walkability and social capital as indicators of quality of life at the municipal and neighborhood scales. Appl. Res. Qual. Life 2010, 6, 201-213. [CrossRef]

22. Holtan, M.T.; Dieterlen, S.L.; Sullivan, W.C. Social Life Under Cover: Tree Canopy and Social Capital in Baltimore, Maryland. Environ. Behav. 2014, 28, 502-525. [CrossRef]

23. Mazumdar, S.; Learnihan, V.; Cochrane, T.; Davey, R. The built environment and social capital: A systematic review. Environ. Behav. 2018, 50, 119-158. [CrossRef]

24. Kwon, M.; Lee, C.; Xiao, Y. Exploring the role of neighborhood walkability on community currency activities: A case study of the crooked river alliance of TimeBanks. Landsc. Urban Plan. 2017, 167, 302-314. [CrossRef] 
25. Ward Thompson, C.; Aspinall, P.; Roe, J.; Robertson, L.; Miller, D. Mitigating Stress and Supporting Health in Deprived Urban Communities: The Importance of Green Space and the Social Environment. Int. J. Environ. Res. Public Health 2016, 13, 440. [CrossRef]

26. Mouratidis, K.; Poortinga, W. Built environment, urban vitality and social cohesion: Do vibrant neighborhoods foster strong communities? Landsc. Urban Plan. 2020, 204, 103951. [CrossRef]

27. Jennings, V.; Larson, L.; Yun, J. Advancing Sustainability through Urban Green Space: Cultural Ecosystem Services, Equity, and Social Determinants of Health. Int. J. Environ. Res. Public Health 2016, 13, 196. [CrossRef]

28. Chan, K.M.; Satterfield, T.; Goldstein, J. Rethinking ecosystem services to better address and navigate cultural values. Ecol. Econ. 2012, 74, 8-18. [CrossRef]

29. Gómez-Baggethun, E.; Barton, D.N. Classifying and valuing ecosystem services for urban planning. Ecol. Econ. 2013, 86, 235-245. [CrossRef]

30. Mazerolle, L.M.; Wickes, R.; McBroom, J. Community variations in violence: The role of social ties and collective efficacy in comparative context. J. Res. Crime Delinq. 2010, 47, 3-30. [CrossRef]

31. Berg, M.T.; Rengifo, A.F. Rethinking community organization and robbery: Considering illicit market dynamics. Justice Q. 2009, 26, 211-237. [CrossRef]

32. Carr, P.J. Clean Streets: Controlling Crime, Maintaining Order, and Building Community Activism; New York University Press: New York, NY, USA, 2005.

33. Pabayo, R.; Grinshteyn, E.; Avila, O.; Azrael, D.; Molnar, B.E. Relation between neighborhood socio-economic characteristics and social cohesion, social control, and collective efficacy: Findings from the Boston Neighborhood Study. SSM Popul. Health 2020, 10, 100552. [CrossRef]

34. Nguyen, D. Evidence of the Impacts of Urban Sprawl on Social Capital. Environ. Plan. B Plan. Des. 2010, 37, 610-627. [CrossRef]

35. Miller, P.M. Community-Based Education and Social Capital in an Urban After-School Program. Educ. Urban Soc. 2012, 44, 35-60. [CrossRef]

36. Silva, R.R.S.; Biondi, D. Avaliação da preferência paisagística no Jardim Botânico de Curitiba, Paraná, Brasil. Rev. Soc. Bras. Arborização Urbana 2013, 8, 39-53. [CrossRef]

37. Howley, P. Landscape Aesthetics: Assessing the General Publics' Preferences towards Rural Landscapes. Ecol. Econ. 2011, 72, 161-169. [CrossRef]

38. Milcu, A.I.; Sherren, K.; Hanspach, J.; Abson, D.; Fischer, J. Navigating conflicting landscape aspirations: Application of aphoto-based Q-method in Transylvania (Central Romania). Land Use Polity 2014, 41, 408-422. [CrossRef]

39. Tang, I.C.; Sullivan, W.C.; Chang, C.Y. Perceptual evaluation of natural landscapes: The role of the individual connection to nature. Environ. Behav. 2014, 1-23. [CrossRef]

40. Richardson, E.A.; Mitchell, R. Gender differences in relationships between urban green space and health in the United Kingdom. Soc. Sci. Med. 2010, 71, 568-575. [CrossRef] [PubMed]

41. Jiang, B.; Li, D.; Larsen, L.; Sullivan, W.C. A dose-response curve describing the relationship between urban tree cover density and self-reported stress recovery. Environ. Behav. 2014, 48, 607-629. [CrossRef]

42. Rišová, K.; Sládeková Madajová, M. Gender differences in a walking environment safety perception: A case study in a small town of Banská Bystrica (Slovakia). J. Transp. Geogr. 2020, 85, 102723. [CrossRef]

43. Hidayati, I.; Tan, W.; Yamu, C. How gender differences and perceptions of safety shape urban mobility in Southeast Asia. Transp. Res. Part F Traffic Psychol. Behav. 2020, 73, 155-173. [CrossRef]

44. Hami, A.; Tarashkar, M. Assessment of women's familiarity perceptions and preferences in terms of plants origins in the urban parks of Tabriz, Iran. Urban For. Urban Green. 2018, 32, 168-176. [CrossRef]

45. Hami, A.; Tarashkar, M.; Emami, F. The Relationship Between Women's Preferences for Landscape Spatial Configurations and Relevant Socio-Economic Variables. Arboric. Urban For. 2020, 46, 96-108.

46. Muratore, A.; Earl, J. Improving retirement outcomes: The role of resources, pre-retirement planning and transition characteristics. Ageing Soc. 2015, 35, 1-41. [CrossRef]

47. Carpiano, R.M. Neighborhood social capital and adult health: An empirical test of a Bourdieu-based model. Health Place 2007, 13, 639-655. [CrossRef]

48. Hinkle, D.E.; Wiersma, W.; Jurs, S.G. Applied Statistics for the Behavioral Sciences, 5th ed; Houghton Mifflin: Boston, Germany, 2003; pp. 1-756.

49. Daniel, G. Designing for Gender Equality in the Developing Context: Developing a Gender-Integrated Design Process to Support Dsigners' Seeing, Process, and Space Making. Ph.D. Thesis, University of Washington, Seattle, DC, USA, 2013.

50. Zhang, L.; Messner, S.F.; Liu, J.; Zhuo, Y.A. Guanxi and fear of crime incontemporary urban ChinaBr. J. Criminol. 2009, 49, 472-490. [CrossRef]

51. Armstrong, T.A.; Katz, C.M.; Schnebly, S.M. The relationship between citizen perceptions of collective efficacy and neighborhood violent crime. Crime Delinq. 2015, 61, 121-142. [CrossRef]

52. Hart, T.C.; Colavito, V. College student victims and reporting crime to the police: The influence of collective efficacy. West. Criminol. Rev. 2011, 12, 1.

53. Bahriny, F.; Bell, S. Patterns of Urban Park Use and Their Relationship to Factors of Quality: A Case Study of Tehran, Iran. Sustainability 2020, 12, 1560. [CrossRef] 
54. Wilkinson, D.L. Local social ties and willingness to intervene: Textured views among violent urban youth of neighborhood social control dynamics and situations. Justice Q. 2007, 24, 185-220. [CrossRef]

55. Kim, Y.; Paik, J. The Effects of Family Conflict, Social Support and Self Esteem on Life Satisfaction of the Aged. J. Digit. Converg. 2016, 14, 279-287. [CrossRef]

56. Liu, Y.; Wang, R.; Lu, Y.; Li, Z.; Chen, H.; Cao, M.; Zhang, Y.; Song, Y. Natural outdoor environment, neighbourhood social cohesion and mental health: Using Multilevel structural equation modelling, streetscape and remote-sensing metrics. Urban For. Urban Green. 2020, 48, 126576. [CrossRef]

57. Cao, W.; Li, L.; Zhou, X.; Zhou, C. Social capital and depression: Evidence from urban elderly in China. Aging Ment. Health 2015, 19, 418-429. [CrossRef]

58. Salvatore, M.A.; Grundy, E. Area deprivation, perceived neighbourhood cohesion and mental health at older ages: A cross lagged analysis of UK longitudinal data. Health Place 2021, 67, 102470. [CrossRef] [PubMed]

59. Lee, H.J.; Lee, D.K.; Song, W. Relationships between Social Capital, Social Capital Satisfaction, Self-Esteem, and Depression among Elderly Urban Residents: Analysis of Secondary Survey Data. Int. J. Environ. Res. Public Health 2019, 16, 1445. [CrossRef] [PubMed]

60. Gerino, E.; Rollè, L.; Sechi, C.; Brustia, P. Loneliness, resilience, mental health, and quality of life in old age: A structural equation model. Front. Psychol. 2017, 8, 2003. [CrossRef]

61. Yung, E.H.K.; Ho, W.K.O.; Chan, E.H.W. Elderly satisfaction with planning and design of public parks in high density old districts: An ordered logit model. Landsc. Urban Plan. 2017, 165, 39-53.

62. Bertossi Urzua, C.; Ruiz, M.A.; Pajak, A.; Kozela, M.; Kubinova, R.; Malyutina, S.; Peasey, A.; Pikhart, H.; Marmot, M.; Bobak, M. The prospective relationship between social cohesion and depressive symptoms among older adults from Central and Eastern Europe. J. Epidemiol. Community Health 2019, 73, 117. [CrossRef] [PubMed] 